\title{
Staging Puritanism in the Early 1590s: The Carnivalesque, Rebellious Clown as Anti-Puritan Stereotype
}

ROBERT HORNBACK

Résumé : La représentation, depuis longtemps négligée, de bouffons puritains sur la scène anglaise au début des années 1590 va de façon surprenante à l'encontre des préconceptions modernes. En se servant du souvent imité personnage rabelaisien et «tarltonesque » de "Martin Marprelate (1588-89), ainsi qu'en puisant dans la polémique qui façonnait les Puritains comme des Anabaptistes incultes visant le bouleversement de l'ordre social, certains dramaturges imposèrent sur les Puritains le stéréotype de bouffons carnavalesques et rebelles. Ce stéréotype exerça une telle influence qu'il est devenu difficile par la suite de séparer l'idée du carnaval de sa fonction de caricature anti-puritaine.

I, as noted Puritan historian Patrick Collinson has suggested, the "stage Iinvented . . . Puritanism," much work remains to be done in order to understand more precisely how the stage did so and why its invention was so successful. Notably, though both Collinson and Kristen Poole have established a connection between the Puritan type or persona of the subversive, pseudonymous pamphleteer "Martin Marprelate" (1588-89) and the stereotypical characterizations of the later hypocritical carnivalesque clowns Falstaff/Oldcastle in Henry IV Parts 1 and 2 (1596-98) and Zeal-ofthe-Land Busy in Jonson's Bartholomew Fair (1614), there remain obvious gaps in the evolution of the stage-Puritan type, not only in chronology but also in logic. ${ }^{1}$ For example, it seems important to consider why the antiMartinists' stereotype of Puritans such as Marprelate as subversive, carnivalesque clowns "stuck" - that is, why it seemed to fit this group so neatly. More importantly, though the comic type is already well-defined by the end of the sixteenth century, the evolution of the Puritan stage clown over the course of the early 1590s remains almost a complete blank in existing 
accounts. How, after all, did the stereotype of the subversive and even rebellious Puritan, so pronounced in anti-Martinist rhetoric, evolve on stage over the years immediately following the Marprelate censorship in 1589? Consideration of such issues suggests that many of the stereotypes that we tend to associate solely with more radical Protestant sects, and only during or after the 1640s, were already evolving or in existence in the Elizabethan period. Renaissance English polemic and satire had, in fact, already defined many so-called "Puritan" stereotypes, ${ }^{2}$ which often invert our modern sense of Renaissance Puritans as rigid, orderly, and simply opposed to carnival. Indeed, in the late 1580s and the early 1590s, Puritans came to be stereotyped as rebellious, carnivalesque clowns.

\section{"Setting the head where the foot should be": Puritans and the Historical Origins of Carnivalesque Stereotyping}

Like historian Keith Thomas, I view humor in part as a potentially revealing guide to "past tensions and anxieties." 3 One anxiety historians of Renaissance England, notably Keith Wrightson and David Underdown, have often emphasized as characteristic of the period is the fear of a breakdown of the social order. As Wrightson explains, "In the course of the later sixteenth and early seventeenth centuries, the gathering pace of ... change placed English society under considerable strain. . . . Little wonder, then, that to some ... . it appeared that the very bonds of society were endangered." Similarly, Underdown argues, "Fears of an impending breakdown of the social order [were at] . . . no time ... more widespread, or more intense, than in early modern England." 4 In such a context, any religious unorthodoxy that appealed to, or that was seen as appealing to, the lower classes was especially threatening because heresy was viewed as a forerunner of popular rebellion. Puritans in particular precipitated such anxieties.

At the same time, while the idea of the world upside down had long been familiar, having survived in vestiges of medieval (and earlier pagan) popular culture, what was new in early modern England was that carnival came to be associated with religious satire and stereotypes. Certainly, in the middle of the seventeenth century, during the Revolution, royalists would associate radical sectaries with a world turned upside down. Yet such associations between carnival and radicalism were already long established when, for instance, radical Protestant Henry Denne was compelled in 1645 to make the following disclaimer about his religious tract, Grace, Mercy and Peace:

It hath been . . . mine endeavour . . . to give unto every limb and part not only his due proportion but also his due place, and not to set the head where the foot should 
be, or the foot where the head. I may peradventure to many seem guilty of that crime ... to turn the world upside down, and to set that in the bottom which others make the top. ${ }^{5}$

It is striking, especially given such a harmless title, that Denne would have had to respond to such an accusation. Why would his critics be predisposed to associate his religious ideology with "the world turned upside down," a favorite theme of carnival throughout early modern Europe? ${ }^{6}$ It is equally puzzling that Digger Gerrard Winstanley, far from objecting to associations with "the world upside down," would use similarly inversive rhetoric in 1649 to proclaim that

All men have stood for freedom, . . . and those of the richer sort of you that see it are ashamed and afraid to own it, because it comes clothed in a clownish garment. ... Freedom is the man that will turn the world upside down, therefore no wonder he hath enemies. ${ }^{7}$

Certainly, it strikes a modern reader as curious that anyone would associate religiously-inspired revolution (especially one's own) with "a clownish garment" (one that enemies have apparently previously constructed as shamefully low-class) or "the world upside down."

In fact, however, Puritans were being unfairly associated with this carnivalesque theme much earlier in the period, as they initially resisted an identity which eventually stuck (and which radical reformers ultimately embraced). Richard Hooker, for instance, went so far as to warn that Elizabethan Puritanism, with its opposition to certain kinds of social hierarchy, might cause the world to be "clean turned upside down." Suplication of the Family of Love . . found to be derogatorie in an hie degree, vnto ... the honour of our King, etc., would claim that "the Puritanes would have kings to submit their sceptors, to throw downe their crownes before the Church, yea and to licke vp the dust of the feet of the Church and yielde obedience vnto the presbiterie, and also that themselues, as Kings, and onely Kings shall euerlastingly liue and raigne . . vpon the earth." 9 "Puritanism" was thus already distortedly stereotyped as a radical ideology advocating topsy-turvydom long before the Revolution.

The accusation that Denne would later encounter - that radical Protestants wanted to invert the social order - was indeed an old one, which even Tudor Presbyterians confronted. In Edward VI's reign, extremist, often lower-class Puritans were disappointed that the Reformation had not gone further than it had. Thus, Robert Cowley's An Informacion and Peticion Agaynst the Oppressours of the Pore Commons of this Realme (1548-49) had already asserted the right of Adam's descendants "to the riches and treasures of this world." 10 John Ball's infamous "leveling" rhyme of the 1381 
Peasant Rebellion - "When Adam delved and Eve Span, / Who was then the gentleman?" - was, in fact, not merely a rallying cry of later radicals in the 1640s and 50s but often quoted during Tudor reigns as well. In 1560-62, it was reportedly even a "common saying" of Presbyterian-sympathizer Bishop Pilkington, who added, "How true it is!"11 Following the Marprelate scandal, Richard Bancroft cited the rhyme in his A Survey of Pretended Holy Discipline to associate the Puritans of the 1580s and $1590 \mathrm{~s}$ with the peasant rebels of 1381, just as The Life and Death of Jack Straw (c. 1588-90) did, as we shall see, on the public stage. ${ }^{12}$

A related tactic was the incessant "fear-mongering over Anabaptist tendencies" supposed to be prevalent among Puritans. ${ }^{13}$ Indeed, while most modern scholars would not conceive of the terms Anabaptist and Puritan as interchangeable, they often were. In Basilikon Doron, for instance, James I claimed that the Anabaptists and the Familists were most deserving of the name of Puritan, "because they think themselves only pure." 14 Earlier, during Elizabeth's reign, Archbishop Parker warned that the Presbyterians' "fond faction" aimed at establishing an Anabaptist "Munzer's commonwealth," claiming, "if . . . it will fall out to a popularity, . . . it will be the overthrow of all." ${ }^{15}$ Likewise, Archbishop Whitgift affirmed that Presbyterian literature contained "the very steps and degrees to anabaptism," 16 while Matthew Sutcliffe warned of the dangers of Puritanism by raising the specter of the Anabaptists' recent rebellions in Munster, Amsterdam, and Strasbourg: "The precedents of the Anabaptists, doe teach us what an unbridled thing the people is, where they take the sword to worke reformation with." 17

Clearly, if many in the 1580s and 1590s saw the considerable discontent of the lower sort as a virtual powder keg, religious schism was the fuse orthodox Protestants regularly feared - hence, Sutcliffe's forebodings, as noted above, about "the people ... tak[ing] the sword to worke reformation with." The danger of the situation, according to Whitgift, was that "the people ... are commonly bent to novelties and factions, and most ready to receive that doctrine that seemeth to be contrary to the present state, and that inclineth to liberty." 18 Bancroft was similarly wary of Presbyterianism, "considering the sinister affections of the people, and how easily they are divided and rent asunder." 19 Moreover, as Lord Burghley noted in 1595, "some . . . do secretly entice the vulgar sort to be vehement in desiring" Puritan reform. ${ }^{20}$ Since the Puritans had in fact tried to win popular support for their cause, orthodox Protestants were able to portray them in sinister alliance with what Bancroft called "the lay factious." 21

Such fears probably seemed logical enough, since Presbyterian doctrine was actually opposed to at least some types of ecclesiastical/political hierarchy. After 1560, the marginal notes in the Geneva Bible, the version 
preferred by "Puritan[s] of the Presbyterian variety," 22 which was published in quarto and aimed at a wide circulation, included the seemingly "more seditious sentiments" of Calvin. ${ }^{23}$ Thus when, after disobeying King Darius, Daniel claimed, "unto thee, O King, I have done no hurt," the Geneva margin glosses, "he did disobey the King's wicked commandment [in order] to obey God, and so did no injustice to the King"; Calvin's comment read, "We ought rather to spit in [princes'] faces than to obey them when they ... spoil God of his right." 24 Presbyterian Puritans, following Calvin, believed in the leveling priesthood of all believers and opposed bishops and their imposed Church hierarchy, to such an extent that Puritan "Martin Marprelate Tracts" such as The Epistle (1588) could assert that "all true pastors . . have the same and equall authority among the[m]selues giuen unto them under Jesus Christ the onely head and the chiefe alone universal bishop." 25

The potential dangers of such Puritan leveling tendencies - later tersely summed up by James I's famous remark at the Hampton Conference: "No bishop, no King" 26 — were thus already familiar in the Tudor period, however distortedly depicted. William Tyndale reported to the King and the Lords in 1528 that "heretics would have us down first, and then you, to make all common," 27 a claim that would be repeated later by Bancroft and was virtually commonplace throughout the Elizabethan period. ${ }^{28}$ In An Admonition to the People of England (1589), which appeared during the Marprelate controversy, not only would Bishop Cooper associate the Presbyterians with the Peasant Revolt of 1381 to support an argument aimed at suppressing Presbyterianism, but he would go on to claim:

At the beginning (say they), when God had first made the world, all men were alike, there was no principality, then was no bondage or villeinage; that grew afterwards by violence and cruelty. Therefore why should we live in miserable slavery under those proud lords and crafty lawyers, etc? ${ }^{29}$

Cooper's accusations may have had some basis in fact, for the Puritan Richard Sibbes would later actually profess similar leveling, anti-hierarchical, even if more peaceful, doctrine in his explanation of the Puritans' frequent use of the term "brethren": "If God be a Father, and we are brethren, it is a leveling word; it bringeth down mountains and filleth up valleys. All are brethren." 30

What may seem paradoxical to modern readers is the way that such leveling was represented as carnivalesque inversion of hierarchy: as the Tudor Homilies would have it, "What a perilous thing were it to commit unto the subjects the judgement which prince is wise and godly, . . as though the foot must judge the head." 31 According to such logic, the leveling of hierarchy (hence the subjection of the elite to the will and judgement of the 
common sort) was, in effect, turning the entire world upside down and transforming England into a carnivalesque Land of Cockayne, where all would be held in common. Indeed, all opposition to hierarchy was constructed as effectively "communist" and anarchic, since The Homily of Obedience (1560) claimed, "Take away kings, princes, rulers, ... and such estates of God's order, . . . no man shall keep his wife, children, and possessions in quietness, all things shall be in common." 32 Worse still, Puritan leveling, so the orthodox propagandists warned, would lead to the kind of riotous anarchy and sexual license of Shrove Tuesday and May Day.

\section{"The May-game of Martinisme": Literary Origins of the Carnival-Rebel Puritan Clown Type}

Because Puritans in the Tudor period were being broadly stereotyped as leveling, carnivalesque rebels, carnivalesque comedy came to be linked to Puritan sedition in popular literature, especially after the Puritans used the persona of a clown to subvert the Church hierarchy in the propagandistic Martin Marprelate tracts. These sensational pamphlets, which vented the "mood of angry frustration [of] the extremist fringe of the movement" after it had failed to achieve further ecclesiastical reforms in the House of Commons, ${ }^{33}$ provoked what Christopher Hill has called "the biggest scandal of Elizabeth I's reign." 34 Beyond its scandalous nature, what was unique about the Martinists' brand of Puritan invective — and what made Martin so influential in subsequent Puritan stereotyping - was the use of a clowning style and carnivalesque comic themes. As Martin himself was made to say in Hay [i.e., have ye] any worke for Cooper, "perceiuing the humors of men in these times . . . to be giuen to mirth[,] I tooke that course." Martin understood, he explained, that "[t]he most part of men could not be gotten to read any thing" either about Presbyterian theology or anything critical of the episcopacy: "I bethought mee therefore of a way whereby men might be drawne to do both." He also rationalized his adoption of a clown's pose by observing, "The Lord being the authour both of mirth and grauitie, is it not lawfull in it selfe, for the trueth to vse eyther of these wayes?"35 Employing such a rationale, in true Rabelasian style, the Puritan Martinists used carnivalesque humor to portray the bishops as "redde nose" "boosing mates," 36 who "plaie[d] the fool ... in the pulpit." 37

As many critics have pointed out, Martin's use of the Rabelaisian style was risky, since Rabelais was himself viewed as subversive and heretical: "Gargantua sometimes became a heretic or rebel, not least when the topic included the body - ours and Christ's - or threats to the body ecclesiastic and politic." 38 Martin himself was aware of such dangers, as he insisted from 
the outset that his opponents "neuer slander the cause of reformation or the furtherers thereof in terming the cause by the name Anabaptisterie / schisme / . . . and the men puritans / and enemies to the state." 39 Thus, while Marprelate's often rollicking accusations against the bishops were certainly effective in subverting their authority, the Martinists' strategy was a dangerous one, which would indeed come back to haunt the Puritan movement. In response to Martin's characterization of the bishops and clergy as "so many swine / dumb $\operatorname{dogs} /$. . so many lewd liuers / as theeues / murtherers / adulterers / drunkards ... so many ignorant $\&$ atheistical dolts" 40 in the tracts which began to appear in October $1588,{ }^{41}$ in 1589 , Archbishop Whitgift and, especially, soon-to-be Bishop Bancroft, who advised the commissioning of the anti-Martinist satires, began an equally savage but more wide-spread propaganda campaign against Puritanism that included "over twenty explicitly anti-Martinist works." 42

As a result of these counter-attacks against Martin's supposed "Anabaptisticall" rebellious subversion, even many Puritans, such as Josias Nichols, actually blamed that "foolish jester" Martin, "how justly God knoweth," for inciting antagonism against the godly brethren. After the Marprelate subversion, Nichols bemoaned, "Then did our troubles increase, and the pursuit was hardly followed against us." 43 Partly because of Marprelate, as Elizabethan Puritan leader John Field bemoaned, "we are charged to be heretics, ... anabaptists and I cannot tell what."44 Other Puritans responded ineffectually to the vast propaganda campaign by claiming that "[w]e are no schismatics, no libellers, rebellious or disordered persons," for the years following the Marprelate controversy witnessed a marked increase in Puritan bashing. ${ }^{45}$ By 1601, Thomas Digges could complain that "puritans were trounced and traduced as troublers of the state." ${ }^{6}$ Decades later, Richard Baxter would recall, painfully:

I cannot forget, that in my youth ... the place of the dancing assembly was not an hundred yards from our door, and we could not on the Lord's Day either read a chapter, or pray, or sing a psalm, or catechise, or instruct a servant, but with the noise of the pipe and tabor, and the shoutings in the street continually in our ears and even among a tractable people, we were the common scorn of all the rabble in the streets, and called Puritans, Precisians and hypocrites. ${ }^{47}$

That sober Puritans like Baxter, who clearly disdained raucous festivity, could be numbered among "hypocrites" or that evidently patriotic Puritans could be characterized as "rebellious . . disordered persons" demonstrates how effective Elizabethan anti-Puritan polemic was in defining the carnivalesque-subversive stereotype of the Puritan. 
Such a stereotype was perhaps partly inevitable, however, given that Martin's line of attack was humorously appealing precisely "because it was subversive of degree, hierarchy and indeed the great chain of being itself." 48 Not surprisingly, Queen Elizabeth's government proclaimed that Martin's "secretly published ... schismatical and seditious books" tended to "the overthrow of her Highness lawful Prerogative." 49 Meanwhile, Bishop Cooper added in his Admonition, "I feare he will prove himselfe to bee not onely Mar-prelate, but Mar-prince, Mar-state, Mar-lawe, Mar-magistrate, and all together until he bring it to an Anabaptisticall equalitie or communitie."50 Likewise, the anonymous author of Mar-Martine (attributed to John Lyly) aptly summed up the anti-Martinists' counterattack characterizing the Puritan Martinists as seditious:

Martine the merry, who is now Mar-prelate,

Will prove madde Martine, and Martine mar-the-state. ${ }^{51}$

Similarly, in A Whip for an Ape, Lyly observed that Martin "mocketh Prince and peasants all alike," 52 as he put the leveling question "Why Kings?"53 in Martin's mouth and begged the "Prince" to intervene or risk having Martin "destroy both Church, and State, and all;/ For if t'one faile, the other needes must fall." 54

Like the bishops' dire invective, the anti-Martinists' more humorous attacks threatened that the Puritan opposition to hierarchy would yield an anarchic world turned upside down; in Mar-Martine Lyly warned, "merrie Martin sets the world at ods," 55 while even Puritan-sympathizer Gabriel Harvey claimed that he feared "an Universal Topsy-turvey" or "Upsydowne." 56 Thus, by employing the logic of carnival, anti-Martinists, such as Pasquill, Mar-Martin, Cutbert Curryknave, and Marphoreus (respectively, Thomas Nashe, John Lyly, Robert Greene, and Anthony Munday), were able to exaggerate other carnivalesque characteristics of the Marprelate Tracts to construct the Puritans as ridiculous hypocrites who embodied clownish misrule. For example, one of Nashe's pamphlets refers to a stage portrayal of the supposedly sober Puritan leaders taking part in the oft-mentioned, riotous May-game of Martinisme:

Penry the welchman is the foregallant of the Morrice, with the treble belles. . . Martin himselfe is the Mayd-marian, trimlie drest vppe in a cast Gowne, and a Kercher of Dame Lawsons, his face handsomlie muffled with a Diaper-napkin to couer his beard, and a great Nosegay in his hande. . . Wiggenton daunces round about him in a Cotten-coate [i.e., a fool's long coat], to court him with a Leatherne pudding, and a woodden Ladle. ${ }^{57}$ 
Depicted as the cast of the Morris dance, typically featuring a fool wooing a cross-dressed man, the Puritans were made to embody the misrule of May-day.

Through such seemingly unlikely portrayals, the anti-Martinists bolstered the norm of episcopal hierarchy; they discredited the vociferous Puritan minority by constructing a dismissive stereotype of Puritans as censorious, yet simultaneously hypocritically grotesque. By "imitating . . . that merry man Rablays" 58 (just as Martin had done), orthodox writers were able to portray the Puritans as gluttonous, licentious "Hipocrites and belligods." 59 On stage, for instance, an anti-Martinist play showed a lecherous Martin hypocritically trying to rape Divinity and then "poyson[ing] her with a vomit" to "make her cast vppe her dignities." 60 When it was rumored that Martin had died, one author claimed that "hee had no other refuge but to runne into a hole, and die as he liued, belching"; ${ }^{61}$ his grotesque nature had become a by-word. In sum, in anti-Martinist tracts, Martin, the Puritan, "copulates, vomits, drinks, gorges himself, and gives birth," so that he became "the Bahktinian grotesque body par excellence." 62

With regard to the development of Puritan stage clowns, both sides of the controversy, according to E. K. Chambers, refer in some twelve tracts to the stages' involvement in the Marprelate "war." ${ }^{63}$ In particular, such tracts allude to anti-Martinist comedies appearing on the public stages, as when Pasquill (Nashe) refers in A Countercuffe given to Martin Junior to " $[\mathrm{t}] \mathrm{he}$ Anatomie latelie taken of [Martin] . . . by launcing and worming him at London vpon the common Stage." 64 Apparently, the playwrights were quite prolific in penning comedies at Martin's expense, since, after they were censored, Lyly complained that if only "those Comedies might be allowed to be plaied that are pend, ... [Martin] would be deciphered" (i.e., understood and exposed) ${ }^{65}$ Despite Lyly's complaint, the evidence clearly indicates that a substantial number of "Comedies" had already been staged. Martin-sympathizer Gabriel Harvey, for instance, complained of those "that have the stage ... and can furnish-out Vices, and Devils at their pleasure" to mock Martin. ${ }^{66}$ Another pamphlet, Martins Months Minde, claimed that "everie stage Plaier made a jest of him," so that Martin "took it very grievously, to be made a May game upon the stage - the actual stage at 'The Theater'," according to the marginal note. ${ }^{67}$ Because of allusions to The May-game of Martinisme, "mentioned separately in three anti-Martinist pamphlets,"68 it would seem that anti-Martinist May-games actually appeared on stage. Ironically, given their hostility to such carnivalesque festivity, and, in particular, their later outrage at the Book of Sports (1617-18), which they called the "morris book," Puritans were made to embody the very May Day Morris dance - on both page and stage - that was anathema to them. So complete, 
in fact, was Martin's identification with anti-Puritan clowning on the stage that the author of Pappe with an Hatchet (1589), apparently Lyly, referred to Martin as "A stage plaier, though he bee but a cobler by occupation." 69

Eventually, in 1589, the Privy Council wrote that "there hathe growne some inconvenience by comon playes and enterludes in and about the Cyttie of London, in [that] the players take upon themselves to handle in their plaies certen matters of Divinytie and of State, unfitt to be suffred." 70 In response, in the same year, Sir Edmund Tilney, Master of the Revels, ordered the theaters to stop producing anti-Martinist satire and closed the theaters temporarily. Tilney and the Privy Council apparently planned to permit the Lord Mayor, an enemy of the players and a Puritan himself, to appoint representatives to censor "suche partes and matters as they shall fynd unfytt and undecent to be handled in playes, bothe for Divinitie and State."71 Yet this degree of censorship certainly did not occur before Martin's tracts and the anti-Martinists' numerous pamphlets and comedies had presented depictions of Puritan clowns that reinforced increasingly prevalent stereotypes. Indeed, in 1589, "Martin Junior" complained bitterly that the stage players, "in the action of dealing against Maister Martin, haue gotten them many thousande eie witnesses, of their wittelesse and pittifull conceites."72 In any case, evidence suggests that censorship of anti-Puritan sentiments was short-lived, limited, or ineffectual, as several stage clowns in the $1590 \mathrm{~s}$ continue to be associated with the carnivalesque clown-rebel Puritan stereotype. Such typing is hardly surprising, since the carnivalesque Martin Marprelate - virtually a "stage plaier" himself — was frequently branded a traitor after he had defiantly railed against the bishops in The Epistle that "Martin doth proclaim open war against you,"73 while openly admitting in The Protestacyon " $[\mathrm{t}]$ hat reformatio[n] can not well cum to our church withe out bloude."74

\section{Carnivalizing Rebellion, Appropriating Tarlton: Carnivalesque Puritan Rebels on Stage in the Early 1590s}

Despite the censorship of 1589 and the temporary closure of theaters in that year, commentators have identified a number of carnivalesque clowns in the early 1590 s who are not merely subversive but actually rebellious. However, perhaps because of an exaggerated idea of the effectiveness of such censorship, the possible link between their misrule and contemporary orthodox Protestant satire has been overlooked. Richard Helgerson's essay, "Staging Exclusion," offers an instance of such an oversight. Focusing on clowns, such as Jack Cade in Shakespeare's The Firste part of the Contention betwixt the two famous Houses of Yorke and Lancaster (2 Henry VI [c. 1591-92]), 
Helgerson demonstrates that "[i]n the theater, carnival and clowns were regularly a part of popular revolt" and that in the histories "carnival is severely punished." 75 Moreover, Helgerson observes, plays such as Jack Straw (c. 1588-90) also "associat[ed] rebellion with carnival," while in revisions of Sir Thomas More (1593) "rebellion is systematically carnivalized"76 to meet the approval of the Master of Revels after he had censored the play. ${ }^{77}$ Helgerson, however, views such systematic "carnivalization" of rebellion as part of Shakespeare's company's attempt "to exclude and to alienate ... the folk"78 in order to appeal to an elite audience, thereby serving the company's own elite aspirations: "Festivity discredited rebellion; rebellion discredited festivity; and both discredited the clown and the common people he represented." 79

One problem with such an argument is that, if it were true, laughter at clownish ignorance should have been a novelty or innovation, a sign of the company's supposed growing elitist sophistication. In actuality, however, laughter at ignorant, low-class carnival clowns was far from new in the theater. Witness, for instance, the popularity of the most famous clown in the Elizabethan era, Dick Tarlton, who, David Wiles argues, simultaneously embodied the ignorant rustic and the carnivalesque "Lord of Misrule" on the Renaissance stage in the early 1580s. Tarlton, Wiles observes, relied on "enactments of 'misrule' to create a sense of release, and ultimately a reaffirmation of hierarchy" and a sense of communal identity in the audience. ${ }^{80}$ Importantly, in so doing, Tarlton's rustic and mechanical clown was often the butt of the joke, since, as Meredith Anne Skura puts it,

much of the humor arose from his being a hick in the metropolis. . . He was a product of the "hostility to the peasant class which characterizes a great part of the literature of the later Middle Ages and the Renaissance" and of the London tendency "to treat in burlesque fashion whatever came from the country." 81

Indeed, Tarlton's comic line often required that he suffer physical abuse:

The most famous of the ... surviving anecdotes about Tarlton's routines tells how, having been boxed on the ear, Tarlton passed the blow on to poor John Cobbler and called him a clown for taking it. A second, the Bookkeeper's recollection in Bartholomew Fair, tells how he was beaten by his fellow Adams. ${ }^{82}$

Other accounts show Tarlton coming on stage to hear "no end of hissing" 83 and audiences throwing tomatoes or pippins at him. ${ }^{84}$ Clearly, then, if the theatres were "staging exclusion," such exclusion cannot be attributed to the new elitism Helgerson conjectures. ${ }^{85}$

Instead, what we must recognize, as contemporaries certainly did, is that the Puritan Martin had appropriated the popular carnivalesque, low- 
class persona of the stage clown Tarlton. The Martinists' appropriation of Tarlton's popular style of clowning for subversive purposes repeatedly invited contemporaries' comparisons to the clown himself. In $A$ Whip for an Ape (1589), for instance, Lyly observed that "Now Tarlton's dead . . . F For knaue and foole thou maist beare pricke and price," 86 and in Marre-Martin (1589), he noted, "These tinkers termes, and barbers jestes first Tarleton on the stage,/ Then Martin in his bookes of lies, hath put in every page." 87 Because the Puritans had adopted Tarltonesque "tinkers' terms," that is, "the language of the street, the slang of the craftsmen, and the dialect of the uneducated," 88 the anti-Martinists, particularly Nashe and Lyly, consistently mocked Martin as "but a cobler by occupation," 89 and Puritans generally as clown-like "ecclesiastical cobler[s]"90 and ignorant "mechanic preachers," a "type often used in anti-Martinist material." 11 It was likewise "a London cobbler, Humfrey Newman, code-name 'Brownbread,' who had joined up as 'common disperser and carrier of Martins Books."'92 Thus, Lyly mockingly refers to a "godly Cobler," 93 just as Nashe scorns sermons by Puritans who "leap from the Coblers stall to their pulpit"94 and derides "[Cutbert] Cli[ff]. the Cobbler and New[man]. . . . [for] ierking out theyr elbowes in euerie Pulpit." 95 In short, Martin's low-class, clownish persona invited, as Charles Nicholl notes, "scoff[ing] at the artisan-provincial base of the movement." 96 Although, as J. W. Martin has demonstrated, there were actual "mechanic preachers" such as Christopher Vitel, ${ }^{97}$ I would argue that it was likely primarily Martin himself who promoted such a stereotype. After all, it was Martin who first referred to himself as "a simple ingram [i.e., a malaprop for 'ignorant'] man" in his opening salvo against the bishops, his 1588 Epistle. ${ }^{98}$

Given that Lyly and Nashe (both dramatists themselves, one of whom certainly penned stage comedies during the Marprelate controversy) were already evoking Tarlton's clowns and zealous rude mechanicals and cobblers in their characterization of Martin in print, it was inevitable that anti-Puritan playwrights would represent Puritans by stereotyping them as ignorant, carnivalesque clowns on stage as well. Thus, a play by the Queen's Men actor-playwright Robert Wilson, The Cobbler's Prophecy (1590), could include Raph, a religiously-inspired ecclesiastical cobbler (married to "Zelota," i.e., a zealot), who, echoing contemporary propaganda, envisions a carnivalesque paradise in which elite and poor will be inverted:

Then these poore that crie,

Being lifted vp on hie,

When you are forlorne,

Shall laugh you lowd to scorne. ${ }^{99}$ 
On the basis of such contemporary stereotypes of Puritan ideology and increasing Puritan bashing in the years following Marprelate, I would argue that Shakespeare and other dramatists depicted clownish rebels, not because they were simply elitist snobs trying to alienate a popular audience in order to elevate themselves, but rather because they feared, along with the orthodox Church hierarchy, that the Puritans were promoting heresy among the lower classes to push their reforms - as propagandist Richard Cosin would have it, seditiously attempting to enlist "the common multitude," "a hundred thousande handes for the advancement of their cause." 100 What the carnivalesque, lower-class rebels in the drama of the early $1590 \mathrm{~s}$ - in the wake of Marprelate's "proclaim[ing] open war" - actually represented, then, was a distorted, comic stereotype of Puritan ideology as ignorant and anarchic, populist, revolutionary heresy; the point was not to attack carnival or the folk but to lampoon Puritanism's supposed "Anabaptisticall” tendencies.

\section{"Your Discipline Is Riot": The Puritan Brethren's “Ill May Day" Riots in Sir Thomas More}

A revealing instance of changing attitudes toward carnivalesque clowning and of anxieties about religious doctrine promoting popular rebellion appears in the revised version of Sir Thomas More (1593). The play was initially written by Anthony Munday, whom Puritan-hunter Archbishop Whitgift had earlier "employed . . . to write rebuttals to the vexing Martin Marprelate." 101 Instructed by the Master of the Revels, Sir Edmund Tilney, to "[1] eaue out . . / y $\mathrm{y}^{\mathrm{e}}$ insurrection / wholy . . \& \& nott otherwise / att your own perilles," 102 subsequent collaborating playwrights curiously added a clown, Ralph Betts, instead. The motive for such an addition was apparently the playwrights' belief that they could gain Tilney's approval merely by "discredit[ing] the actions of the rebels"; 103 the clown would discredit both the rebellion and his rebel compatriots, who are not simply "the folk," but the "simple ingram" or ignorant Puritan "ecclesiastical cobler[s]" so often stereotyped in anti-Martinist tracts.

After all, Sir Thomas More, which includes a depiction of artisan rebels who are sent to the scaffold, was written in the same year that three Puritan leaders were hanged, a year in which Archbishop Whitgift procured a cruel piece of legislation ${ }^{104}$ against "seditious sectaries," which was aimed at Presbyterians (those who "dispute the Queen's authority in Ecclesiastical Cases ... or attend unlawful Conventicles") 105 and "effectively outlawed" the Puritan cause. ${ }^{106}$ Thomas Phelippes noted that "the day after the Lower House had showed their dislike of this bill" (7 April), the Puritan leaders Barrow and Greenwood were hanged ${ }^{107}$ — in hatred of the Commons, some 
said ${ }^{108}$ — and the bill passed on 10 April. ${ }^{109}$ On 29 May the suspected Martinist, Welsh Presbyterian John Penry, was also sent to the scaffold. ${ }^{110}$ Finally, in the same year, Bancroft published both A survey of pretended holy discipline, in which he attacked the Puritans by associating them with the Peasants' Revolt of 1381, and Dangerous positions, in which he claimed, "there is nothing more laboured for, amongst that sect [Presbyterians], th[a]n to thrust their many thousandes . . . into some mutiny or bloudy attempt." 111 Clearly, the time was ripe in 1593 for a play satirizing and stereotyping the harried Puritan minority as populist and rebellious.

It should hardly come as a complete surprise, then, that the artisan rebels in Sir Thomas More are clearly, though economically, characterized as Puritans through their use of Puritan cant. Most notably, two of the rebels, the "Bettses," George and his clownish brother Ralph, are referred to as "these two brethren" (1.1.82). Although scholars have ignored the allusion, perhaps reading it merely as "brothers," the word "brethren" was commonly used by Puritans to refer to fellow believers in the cause. Indeed, as we saw above, Richard Sibbes explained the doctrinal meaning of "brethren" as serving a leveling function. Likewise, Martin Marprelate had incessantly used the words "brethren" and "brothers" both in referring to fellow Puritans and in subversively leveling the bishops. Moreover, in the same year Thomas More was penned, Bancroft was quoting Puritan letters using "brethren" as proof of their seditious confederacy in Dangerous positions:

Salute the brethren . . . the brethren with us here are in health. . . . Let him be accounted among the brethren. . . . I trust you are so linked together, by the bond of brotherly love, and the desire of the pure Discipline of the church, that nothing may sunder you. ${ }^{112}$

On stage, too, the word "brethren" served as recognizable shorthand for characterizing Puritans. For instance, the Puritan in 1 Parnassus greets his fellow Puritans with "Welcome my wellbeloved brethren," 113 and, in Jonson's Bartholomew Fair, the Puritans Zeal-of-the-Land Busy and Dame Purecraft regularly refer to their party as "brethren" or "the brethren." 114 Further characterizing the rebels as Puritans, the speaker using the Puritan term "brethren" in Sir Thomas More, John Lincoln, the leader of the rebels, even speaks of "vild enormities," which was also widely parodied as Puritan cant, "a term in the Puritan anti-theatrical lexicon" that implied "both excessive magnitude and moral transgression," ever since its appearance in Puritan William Rankins' infamous anti-theatrical diatribe, A Mirrour of Monsters (1587). ${ }^{115}$

Most importantly, the play depicts the Puritan rebel "brethren" enlisting "preachers" $(1.1 .91,98)$, who "shall . . openly publish in the pulpit" their 
grievances to incite rebellion. In a particularly charged use of words, we learn that one preacher, Master Doctor Beale (the surname of one of the leaders of the Puritans then voicing their grievances in the House of Commons), agrees to "reform" (1.1.100) the bill of wrongs, and, in the event, it is his sermon that actually incites the rebellion. Just as bishops at the time were linking Puritan preachers to the danger of popular revolt, so the play portrays Puritan reformers as seditious. Indeed, the play depicts the "'Ill May Day' [riots] of 1517 [which] was still a current hobgoblin in the popular mythology," 116 and thereby perpetuates the link between Puritanism and the carnivalesque festivity of May Day in particular already established by Munday and other anti-Martinists in print and on the common stages.

In addition, these rebel "brethren" are emphatically, if inaccurately, depicted as "godly" Puritans by way of their persistent references to God. Although actual Puritans typically opposed taking the Lord's name in vain, zealously persistent references to God regularly served as shorthand-stereotyping for Puritanism on stage. And so, one of the rebel "brethren," or actually, a "sister," the female conspirator Doll Williamson (perhaps representing the "parrats tong[ed]" Dame Margaret Lawson, the "Puritan scold of St Paul's," 117 who was mocked on stage in The Maygame of Martinisme), repeatedly speaks of or invokes God: "[by] Him that bought me" [i.e., "by Christ who redeemed me"] (1.1.56); "God's dear earth" (61); "before God" (95); "Before God" (123); "by the Lord" (134); "Before God, that's as true as the gospel" (2.3.94); "by the Lord" (183-84); and "I do owe God a death" (2.4.113). The crowd of rebels share Doll's apparent zeal as they are twice made to invoke God: "All. [F]or God's sake, read it" (1.1.105); "All. Marry, God forbid that" (2.3.104). Before his execution, Lincoln is similarly pious: "A God's name, let's to work" (2.4.47); "But God forgive them that were the cause of it,/ And as a Christian truly from my heart/ I likewise crave they would forgive me too" (62-64).

Finally, Thomas More brilliantly persuades the zealous rebels to surrender peacefully not only by invoking God and Biblical authority, but by appealing to their strict religious values:

First, 'tis a sin

Which oft th' apostle did forewarn us of, Urging obedience to authority, And 'twere no error if I told you all You were in arms 'gainst God. (2.3.99-103)

Thus, as William B. Long has observed, although "[c]ivil disturbance is a continuing feature of the action of the play, . . . behind each incident is the ultimate evil of disobeying the monarch. Over and over the idea is stated and 
implied that opposition to the king is opposition to God." 118 What I would add to Long's astute assessment is that the play's persistent theme is calculated precisely as a rebuttal to supposed Puritan ideology, as articulated in the Geneva Bible and Calvin's writings. Thus, More's speech goes on to appeal to the Puritans' value of discipline (as in The Book of Discipline) when he disparages their May Day rebellion by claiming that their "discipline is riot" (2.3.121).

The addition of the clown (possibly by Shakespeare) among the Puritan rebels in the post-censor revision further "carnivalizes" them in order to make it appear that the Puritan "discipline is riot" indeed. For example, after Doll Williamson bravely asks to die second, before her husband, the clown ridiculously begs a suit as well: "That as you have hanged Lincoln first and will hang her next, so you will not hang me at all" (2.4.86-87). His cowardice here is a marked contrast to his earlier boasting: "Fire, fire! I'll be the first;/ If hanging come, 'tis welcome, that's the worst" (2.2.75-76). Undercutting the potential for bravery and dignity in the Puritans' rebellion is the clown's function throughout, as when he begins 2.1 using the imagery of the grotesque belly:

Come come, we'll tickle their turnips, we'll butter their boxes. Shall strangers rule the roost? Yes, but we'll baste the roast. Come, come, a-flaunt, a-flaunt. (1-3)

The added clown's brief lines associate him with disorder, the grotesque, and stupidity. Apparently, the playwrights believed that associating Puritan rebellion with a stupid, grotesque clown would be enough to undercut the danger. This belief, whether actually successful in appeasing the censor or not, was solidly founded on a widespread Puritan stage-clown tradition.

\section{"When Adam delved": Staging Lower-Class Puritanism in the Peasant Revolt of 1381}

An earlier play associating carnival and rebellion, The Life and Death of Jack Straw (c. 1588-90), which depicts the Peasants' Revolt of $1381,{ }^{119}$ may have been performed during the sensational Marprelate scandal, when Church propagandists were associating the Presbyterians with this rebellion, as in A Whip for an Ape (1589) (subsequently reprinted as Rimes against Marprelate [1589]): "Martins mate Jacke Strawe would alwaies ring / The Clergies faults, but sought to kill the King." ${ }^{20}$ In Jack Straw, the function of the stupid clown, Tom Miller, among Puritan rebels in this play, as with the later clown Ralph Betts in the post-censorship version of Sir Thomas More, is to undercut any suggestion of dignity, seriousness, or heroism in the depiction of Puritan rebellion. For instance, when Jack Straw kills a man, 
Tom foolishly proclaims, "A small matter to recouer a man that is slaine, / Blow wind in his tayle, and fetch him againe." 121 Later, he boasts before battle that "for a little Captaine I haue the vantage of you all, / For while you are a fighting, I can creepe into a quart pot / I am so small" (11. 260-62). We also see Tom preparing to "make good cheare" (1. 495) with a goose and cheerfully resigning himself to death: "Well if wee shall be hangd it is but a follie to be sorrie, / But goe to it with a good stomacke" (1l. 793-94). Nonetheless, it is the "starke nidiot" (1. 837) Tom who bluntly reveals the hypocrisy of the Puritan Parson (whom Jack calls an "honest Priest" [1. 64]), when he observes:

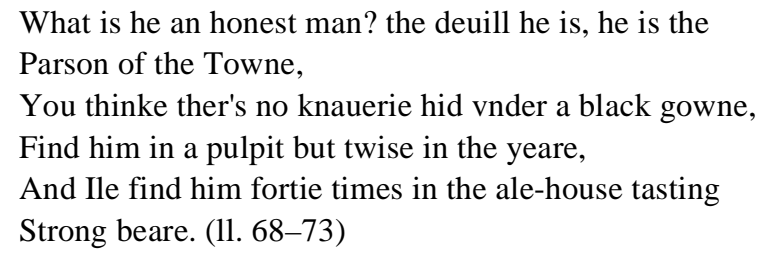

Not only does the clown accuse the Parson in terms employed by both sides of the Marprelate controversy that was apparently raging in London at precisely this time, but he calls him "the Parson of the Towne" (11. 68-69), which may allude to Chaucer's "Persoun of a Toun," whom the Host slanders as a "Lollere," or Lollard, like the proto-Puritan Oldcastle. ${ }^{122}$

Not surprisingly, then, these rebels and their Parson, like the rebels and preacher in Sir Thomas More, are clearly represented as Puritans. Like the Puritan rebels in Sir Thomas More, the clowns in Jack Straw zealously invoke God: "godamercie" (11. 49 and 515); "God wot knowes" (1. 61); "God doth not this ... allow" (1. 81); "by gogs bloud" (11. 252, 286, 510); "God vs all deliuer" (1. 822); "God will give you strength" (1.862). Most importantly, the rebels are incited to riot by a preacher, as are those in Sir Thomas More. Indeed, Parson John Ball addresses his confederates in the leveling Puritan familiar form: "Brethren, brethren" (1. 84). Furthermore, he employs the scriptural authority repeatedly invoked by Puritans and popularly associated with their stereotypical opposition to hierarchy in a doggerel verse-sermon to the rebels that justifies sedition:

England is growne to such a passe of late,

That rich men triumph to see the poore beg at their gate.

But I am able by scripture before you to proue,

That God doth not this dealing allow nor loue.

But when Adam delved and Eve span,

Who was then a Gentleman.

Brethren, brethren, it were better to haue this communitie, 
Then to have this difference in degrees...

But merrily with the world it went,

When men eat berries of the hauthorne tree, ...

Brethren mine so might I thriue, ... .

But follow the counsell of Iohn Ball,

I promise that I loue yee all:

And make diuision equally,

Of each mans goods indifferently,

And rightly may you follow Armes,

To rid you from these ciuill harmes. (11. 78-109; emphasis added)

Parson Ball's opposition to "this difference in degrees" (1. 86) reflects the popular idea, based on radicals' interpretation of the Book of Genesis and upon a distorted view of "Puritan" ideology generally, that so-called Puritans wanted to abolish social hierarchies. Of course, the Parson is also given the familiar line, "When Adam delved and Eve span, / Who was then the gentleman?" (11. 82-83), a direct quote from the historical John Ball's verse, which was often cited by "Puritans." 123

Naturally, as Ball clearly intended, the moral the rebels in Jack Straw take from their Puritan Parson's preaching is that hierarchy is unjust, so that their goal is to live as lords of misrule in precisely the kind of laborless land of carnival ease people associated with the Anabaptists: "Ere wele be pincht with pouertie, / To digge our meate and vittels from the ground ... / We will be Kings and Lords within our selues" (11. 715-19). Later, the Puritan Parson again invokes religious authority for this carnivalesque cause, as he promises the rebels in doggerel verse that "God will give you strength and might / And put your enemies to flight / For of mine honestie your quarrels right" (11. 862-65). Even after the rebellion fails and he is about to be executed, this emblem of "knauerie hid vnder a black gowne" (1. 70), has no remorse for the bloodshed his sermon has incited: "And what I said . . . I repent not, / And if it were to speake againe, / Euerie word should be a whole sermon, / So much I repent me" (11. 1123-26). Such a depiction of a destructive Puritan manipulating clownish, rebel followers plainly constructed the leaders of the "brethren" as seditiously provoking the "lay factious," who in turn were stereotyped as pathetically ignorant dupes.

\section{"Stricte Stupido": The Ignorant Puritan Clown-Type}

Although carnivalesque stereotyping continued to be a part of the depiction of Puritan stage clowns throughout the 1590s, it is important to emphasize that another characteristic of the type was in fact stupidity or ignorance. Shockingly, in fact, stupidity alone could often serve as recognizable shorthand characterization for the Puritan stage clown. Perhaps the most obvious 
example of the merely stupid Puritan stage clown in the 1590s is "stricte Stupido" in 1 Parnassus (c. 1597), who is marked as a Puritan at his first entrance, when he speaks of God and his own godly "brethren":

Welcome my wellbeloved brethren, trulie (I thanke god for it) I have spent this day to my great comfort; I have (I pray god prosper my labours). (11. 322-24; emphasis added)

Whereas Stupido's strictness is taken for granted, characters' contempt for his Puritanism is inextricably linked to his stereotypical stupidity. Amoretto, for instance, rails in Act 3:

[S]tricte Stupido that puling puritane, A moving piece of clay, a speaking ass,

A walking image and a senseless stone.

If they be of his humor, I care not I

For such pure, honest seeminge companie. (11. 410-15; my emphasis)

Similarly, Philomuses mocks the Puritan, saying, "Stupido that plodding puritane? That artlesse ass \& that earthcreeping dolt" (11. 417-20; emphasis added). Given often one-sided modern preconceptions about Puritans as literate and learned in doctrine, a stereotype characterizing Puritans as ignorant seems implausible, to say the least.

Yet, despite many Puritan leaders' undoubted learning, the movement included many enthusiastic, unlearned "brethren" trapped by what Ben Jonson, referring to "Puritan" prelapsarian theology in Bartholomew Fair, cleverly called their "original ignorance" (1.4.140). That there was some merit to Jonson's characterization of Puritans as "a herd of . . . proud ignorants" (5.2.39) who went gadding to sermons is evident in the fact that even some learned Puritans themselves made similar admissions with shame, regret, or disillusionment, for, as Thomas Hooker observed, "[as for] the meaner sort of people, it is incredible what ignorance is among them." 124 And, in spite of all their faith in and theories about the efficacy of a preaching ministry, in everyday practice, many Puritans like Richard Younge found that most of the faithful were regrettably sermon-proof, because "[p]eople heare much, [but] learne little." 125 The disillusioned Puritan Richard Baxter, who had himself placed so much emphasis on a preaching ministry, conceded that preaching often failed to edify uneducated believers, since the sermons "over-run their understandings and memories." 126 As Baxter admitted, "Many men have that in their minds which is not ripe for utterance; and through ill education and disuse, they are strangers to the expressions of those things which they have some Conceptions of." 127 Finally, yet another reason for stereotyping Puritans as ignorant can be traced, once again, to the persona of Marprelate himself, who, as we saw, "adopted the dialect of the uneducated" 128 and even referred to himself as "a simple ingram man" in 
order to gain popular support - all of which contributed to the clownish, "Anabaptisticall" caricature of Puritans.

\section{Strict and Stupid Rebellion: Jack Cade's Religiously Inspired, Carnivalesque "Reformation"}

By exploiting the stereotype of the carnivalesque, often ignorant, Puritan rebel while exaggerating that of the zealous censor, Shakespeare produced one of the most famous stage clowns of the 1590s. The most striking example of the stereotype of the simultaneously stupid, rebellious, carnivalesque, yet paradoxically strict, Puritan clown appears during the period of intense anti-Puritan propaganda and persecution between 1589 and 1593 in the persons of the ignorant Jack Cade and his clownish artisan faction in Shakespeare's 2 Henry VI. ${ }^{129}$ In fact, in 4.2, the first scene with the rebels, Cade's followers are immediately characterized as Puritan "mechanic preachers" when they echo Puritan cant, speaking of their "vocation" ("Labour in thy vocation"" [13]) as well as of "sin" and "iniquity" ("Then is sin struck down like an ox, and iniquity's throat cut like a calf" [23-24]). In the Arden Shakespeare edition, Ronald Knowles includes the following note for the latter quotation: "reminiscent of Old Testament rituals of atonement for 'sin' and 'iniquity' using various beasts, including the calf and bullock. See Leviticus, 9 and 16."130

Cade's own second line, with its zealous rhetoric and biblical echoes of scripture from Leviticus, Ezekiel, and Luke - scripture that had "provided a revolutionary agenda for the Anabaptist leaders"131 — immediately marked him as a Puritan, too: "For our enemies shall fall before us, inspired with the spirit of putting down kings and princes" (4.2.30-31). The reference to "the spirit" as a motivating force calls to mind the speech of one of the most famous early modern stage Puritans, Zeal-of-the-Land Busy, who likewise speaks repeatedly of the "spirit": "I was moved in spirit" (Bartholomew Fair, 3.6.79); "Friend, I will leave to communicate my spirit with you" (4.6.93); "I will not fear to make my spirit and gifts known!" (5.5.38); and "Yes, [my vocation] is of the spirit" (5.5.52). More particularly, Cade's religiously coded, "inspired" rebellion echoed accusations in recent anti-Martinist tracts that no place would suit the Puritans but "Bedlam and Bridewell, so mad they are, and so bad they are, and yet all proceedes of the spirit. I thinke thou [Martin] art possest with the spirites of Iacke Straw \& the Black-smith, who, so they might rent in peeces the gouernment, they would drawe cuts for religion." 132 That Cade's religious rhetoric of inspiration was also meant to evoke Puritan rebellion is further clear from Nashe's 
fictive description of the "Anabaptisticall Brother[s]"133 of Munster in The Unfortunate Traveller (1594):

Verie deuout Asses they were . . . : why, inspiration was their ordinarie familiar, and buzd in their eares like a Bee in a boxe euerie hower what newes from heauen, hell, and the land of whipper-ginnie: . . . they would vaunt there was not a pease difference betwixt them and the Apostles; they were as poore as they, of as base trades as they, and no more inspired than they, and with God their is no re-spect of persons. $^{134}$

Nashe, incidentally, goes on to make explicit his intended identification of Anabaptists with Puritans when he writes, "Heare what it is to be Anabaptists, to be Puritans, to be villaines; you may bee counted illuminate botchers for a while, but your end will bee, Good people, pray for vs." 135 There can be little doubt, therefore, that an audience in the early 1590s would have recognized Cade's line, "inspired with the spirit of putting down kings and princes," as the Puritan cant that it was.

Cade employs other obvious Puritan rhetoric. In fact, he even invokes the cause of Puritanism as he "vows reformation" (4.2.57-58). Cade goes on to claim that in one livery all "may agree like brothers" (67), that is, like the anti-hierarchical Puritan brethren; invokes the now-familiar Biblical authority of the lack of hierarchy in Eden to support his cause ("And Adam was a gardener" [121]), often invoked to justify and promote lower-class revolutionary heresy (recall "When Adam delved ... "); shares the Puritans' suspicion of devils when he accuses an opponent of having "a familiar under his tongue" (4.7.98-99); claims to be "[i]n despite of the devils and hell" (4.7.201-2); boasts that he could defy "ten thousand devils" (4.9.58-59); and "pray[s] God" (4.9.56), "beseech[es] God" (4.9.36), invokes "God's curse" (4.7.173), and piously objects when a man "speaks not i'God's name" (4.7.99). In an Elizabethan context, such rhetoric would have made Cade sound not merely Christian, but like one of the zealous brethren.

Cade is also marked as a Puritan in that, like the earlier Martin Marprelate in anti-Martinist comedies, he is represented as a figure of carnival. Indeed, as was Martin in The May-game of Martinisme, Cade is made to embody the Morris dance, the traditional dance particularly associated with May Day festivity, since, as York observes, "I have seen / Him caper upright like a wild Morisco, / Shaking the bloody darts as he his bells" (3.1.364-66). Given the association of Puritan Martinism with the carnivalesque (e.g., gluttonous eating, drinking, vomiting, lechery) — particularly with the May Day Morris on stage and in pamphlets - and the depiction of an anachronistically Puritan Ill May Day Riot in Sir Thomas More, I would suggest that 
in the theater $c$. 1591-92, Cade's association with the Morris almost inevitably signaled that he was a stereotypical carnivalesque Puritan.

Curiously, while commentators have observed Cade's "concern . . . to . . . establish himself as a carnival king or Lord of Misrule," 136 they have failed to recognize that his supposed revolutionary "reformation" (4.2.58) echoed positions that, as we have seen, were emphatically, however unfairly, stereotyped as Puritan ideology. Like the Puritan rebellion anachronistically depicted in Jack Straw, Cade's "vow" of "reformation" (57-58) is primarily a call to a grotesque Land of Cockayne or Lubberland that includes taking "the commonwealth and turn[ing] it" (5), "mak[ing] it a felony to drink small [i.e., weak, watered down] beer" (60), commanding that "the Pissing Conduit run nothing but claret wine" (4.6.3), promising that "All the realm shall be in common" (4.2.60-61), and declaring, "henceforward all things shall be in common" (4.7.16). Of course, Puritans of the Anabaptist variety, in particular, actually advocated a social order in which all things were to be in common, as they were in Eden. (Recall the fear-mongering about Marprelate creating "an Anabaptisticall equalitie or communitie" in Bishop Cooper's Admonition [1589] or Parson Ball's revolutionary sermon ["Brethren, brethren, it were better to haue this communitie, / Then to have this difference in degrees"] in Jack Straw.) Because Anabaptist Puritans actually believed that social hierarchies should be abolished, since "When Adam delved and Eve span," there "was then [no] gentleman," the Puritans' zealous attempts at reform are distorted in the representation of Cade's rebellion and "reformation," in that he is "inspired with the spirit of putting down kings and princes" (4.2.30-31), since "Adam was a gardener" (4.2.121). In the end, Cade actually becomes a carnival king for a day (though he envisions a longer reign) and refers to his followers as "Fellow-kings" (148-49), thereby embodying the anxiety which we have previously witnessed many of his contemporaries voicing that "the Puritanes would have kings to submit their sceptors . . . and yielde obedience vnto the presbiterie . . that themselues, as Kings, and onely Kings shall euerlastingly ... raigne ... vpon the earth." Likewise, evoking the stereotype of Familists, whom contemporaries like Nashe called "adulterous Familists," 137 Cade later declares lustfully that wives shall be "in common" too, since, he adds, "we charge and command that their wives be as free as heart can wish or tongue can tell" (4.7.113-15).

As much as associations with Marprelate or fear-mongering about Puritans' supposed leveling tendencies, Cade's promotion of carnivalesque gluttony and lechery recalled frequent "satiric denunciation of [Puritans] as mere hypocrites, who oppose[d] Lenten observances while claiming to uphold a high standard of abstemious conduct." 138 The anti-Puritan satirist John Taylor was far from original in claiming a generation later in Iacke-a- 
Lente that many crassly wished to "drive away Lent, (for a Dogge, a Butcher, and a Puritan, are the greatest enemies hee hath)." 139 The satiric association of censorious Puritans with hypocrisy was already a by-word by the early 1590s because of Puritan opposition to Lent. Such hostility to fasting, after all, seemed a contradiction to the Puritans' professed abstemiousness. It was precisely this logic that had motivated Nashe to call Puritans "Hipocrites and belli-gods, that deuoure as much good meat in one of [their] brotherly loue meetings, as would wel-nye victuall the Queenes ships a whole moneth." 140 Taylor, then, was only advancing a prevalent stereotype (one especially promoted by his hero Nashe) when he described the "superfluous feasting or gormandizing" at the Puritans' supposed "pa[u]nch-cramming assembly": "the disordered businesse is so ordered, that it must bee either in Lent, vpon a Friday, or a fasting day: for the meat doth not relish well, except it be sawc'd with disobedience," for "[t]hen all the zealous Puritans will feast,/ In detestation of the Romish beast." 141 For contemporaries, the "truth" in the stereotype of the gluttonously carnivalesque hypocrite was seemingly confirmed by the fact that Banbury, a center of zealous Puritanism, was paradoxically famous for its carnivalesque cakes, ale, and cheese: the gluttonous Zeal-of-the-Land Busy himself is a Banbury Puritan. In short, "[c]ontemporary references to puritan hypocrisy are frequent." 142

Furthermore, like the anti-Martinist depictions of Marprelate, or indeed like later characters such as Master Ful-Bellie in The Puritan (1607), Zeal-of-the-Land Busy in Bartholomew Fair (1614), or Plumporridge in Middleton's Inner Temple Masque (1619), Jack Cade demonstrates the early modern tendency to characterize the Puritan as embodying paradoxical stereotypes. As Poole explains, "while accusations of antinomianism spurred legends of unbounded gastronomic and libidinous desires, the stricter reformers' moral prohibitions against weekend festivities conferred upon them a reputation as killjoys," so that rather than choosing between these "competing stereotypes" satirists often created representations drawing upon "both at once." 143 At the same time, Marprelate himself had combined, according to Neil Rhodes, "the festive tradition of saturnalian clowning and the morally censorious tradition" of preaching, ${ }^{144}$ preparing for subsequent depictions of Puritans.

Like that of Jack Straw, Cade's misrule is radically different from traditional festivity in that it is not merely a harmless release from, or humorous parody of, the everyday, but a brutal, deadly, frightening version of a world upside down. The paradox of Cade's nightmarish Puritan misrule is that it is stereotypically strict and often grounded in moral prohibition, but in an upside-down, anarchic way, as when he makes it a "felony to drink small beer." We thus see Cade strictly enforcing disorderly misrule, as he 
commands the deaths of the following: a man who complains that Cade's lieutenant has raped his wife, since all have a strictly enforced right to what Cade, evoking Anabaptist communal rhetoric, refers to as "her common place" (4.7.125); ${ }^{145}$ a fellow rebel ignorant of Cade's recent declaration that "now henceforward it shall be treason for any that calls me otherwise than Lord Mortimer" (4.6.4-5); and a Clerk and a lord for the "monstrous" crime of literacy (4.2.77).

Cade's characteristic violence (e.g., "Give him a box o'th'ear" [4.7.77] and "take him hence: cut out his tongue for cogging, hough him for running, and, to conclude, brain him with his own mace" [129-31] ${ }^{146}$ ) further reflects a Puritan stereotype developed in the Marprelate tract war. As Donna B. Hamilton has demonstrated, one characteristic of Martin Marprelate's idiom was his rhetorical use of "the physical violence of hitting,"147 likely appropriated, I would add, from the physical knock-about made famous by Tarlton. The "ongoing verbal battles" thus came to be represented in terms of clownish "blows, hits, strokes, slaps, and cuffs." 148 Most notably, Hamilton observes,

\begin{abstract}
Martin speaks of [the Puritan] Cartwright's reply to Whitgift as "the blows which Master Cartwright gave him in the cause" (Epistle 18). He warns Dean Bridges that if he tries to reply to the puritans, he will be beaten back with better answers, or, as he calls them, fists: "You will shortly ... have twenty fists about your ears" (Epistle 18). ${ }^{149}$
\end{abstract}

Not surprisingly, the anti-Martinists were quick to point out the loutish violence suggested by Martin's persona. Bancroft sermonized at Paul's Cross about how "Martin . . . threateneth Fists," 150 while Sutcliffe derided:

He sayth, that ... where he threatneth, that Dr Bridges shall have XX fistes about his eares, meaneth that many shall write against him: A goodly comment: As if puritanes wrote with fistes, rather thean with fingers: which may very well bee; for theyr writing is seditious, rude, and uncivill. ${ }^{151}$

Likewise, anti-Martinist titles, such as A countercuffe given to Martin Ivnior and Pappe with an hatchet. Alias ... A Countrie cuffe, that is, a sound boxe of the eare for the idiot Martin, emphasize Martin's own violent rhetoric. Martin's appropriation of Tarlton's slapstick clowning thus inadvertently served to stereotype him and Puritans generally as violently "rude," "Countrie" clowns. And when Cade orders one of his revolutionaries to "[g]ive [Lord Saye] a box o'th'ear" - an allusion, Knowles notes, to an anti-Martinist tract ${ }^{152}$ - Shakespeare is making Cade enact Martin's notoriously violent Puritan persona.

Critics have long noted that Cade's scenes include self-conscious allusions to the recent Marprelate controversy. Nicholl observes several parallels to Nashe in particular: 
It has been argued that Nashe himself contributed some scenes to the first two parts of Henry VI. There are, certainly, some striking parallels with phrases in Nashe's own pamphlets. . . . The Jack Cade scenes in 2 Henry VI have the atmosphere of Nashe's comic prose but, as Rhodes suggests, they could be Shakespeare's own exploiting of "the stylistic innovations of the Marprelate controversy." An early collaboration between Shakespeare and Nashe remains tantalizingly possible. ${ }^{153}$

Nashe's Unfortunate Traveller, in its depiction of the Munster Anabaptists' revolution, undoubtedly reveals a flair for the kind of anti-masquing evident in Cade's scenes:

[F]lourishing entered Iohn Leiden the Botcher in the field, with a scarffe made of lysts like a bow-case, a crosse on hys breast like a thredbottome, a round twilted Taylors cushion buckled like a Tankard-bearers deuice to his shoulders for a target, the pyke where-of was a pack-needle, a tough prentises club for his spear ... and on his head for a helmet a huge high shooe with the bottome turnd vpwards, embossed as full of hob-nayles as euer it might sticke: his men were all base handicrafts, as coblers and curriers and tinkers, whereof some had barres of yron, some hatchets, .. . some dung-forkes, some spades, some mattockes, . . . for their weapons: he that was best provyded [was] . . . brauely fringed with cop-webs to fight for him. ${ }^{154}$

Here, it is tempting to conclude that Nashe's colorful description is an imaginative reconstruction of the staging he at least witnessed (if not collaborated in) of 2 Henry VI. In any case, the description is certainly consistent with Cade's own recent embodiment of the stereotype of Puritans in the early 1590s as inciting "Anabaptisticall," lower-class heresy.

In addition to his "Martin-like" violence and similarity to contemporary depictions of the Anabaptists, Cade's comically absurd yet murderous antipathy toward literacy is part of the normative comic function of anti-Puritan stereotyping in the play. After all, anti-Puritan propagandists such as Sutcliffe claimed that among Puritans, "[1]earning hath lost almost all reputation," since "these unlearned and unwise consistorians declame against learning," 155 while Marprelate himself spoke of the bishops' "bomination learning." 156 At the same time, Cade's opposition to literacy makes him a distorted comic caricature of one of the most fundamental Puritan tenets, one that separated Puritans from the orthodox Church: the Puritans' insistence upon having a preaching rather than a reading ministry. Their outright hostility to the conformist Church's Book of Common Prayer was evident, for instance, in the famous Puritan tract, A View of Popish Abuses Yet Remaining in the English Church (1572):

By the word of God, it is an office of preaching, they make it an office of reading: Christ said go preach, they in mockery give them the Bible.... [T] 
to feed God's lambs, and yet with these, such as are admitted and accepted, as only are bare readers that are able to say service and minister a sacrament. And that is not the feeding that Christ spake of, the scriptures are plain. Reading is not feeding, but it is as evil as playing upon a stage, and worse too. For players yet learn their parts without book. ... 157

Ironically, most Puritan leaders (other than the "mechanic" or "cobler" preachers Nashe complained of, no doubt) actually favored a more learned ministry capable of more than merely reading. Nonetheless, A View of Popish Abuses reveals that they often voiced their opposition to a so-called "reading ministry" in such overstated, even ridiculous, terms that it ultimately required very little exaggeration for playwrights like Shakespeare to satirize them as actually favoring illiteracy. By omitting the finer points, playwrights could defend the norm of conformist ministry against Puritan attacks by satirically misrepresenting the Puritan position as the ridiculous extreme, "Reading ... is . . . evil."

Shakespeare does indeed characterize Cade as the kind of illiterate zealot, violently declaiming against literacy as blasphemous evil, to which Sutcliffe refers. When informed that the clerk of Chatham "can write and read" (4.2.75), for instance, Cade exclaims "O, monstrous!" (77). The Clerk's literacy also makes him "a villain" (79) and "a conjuror" (81). After Cade examines the clerk with "Dost thou use to write thy name? Or hast thou a mark to thyself like an honest plain-dealing man?" (89-91), and it is discovered that the Clerk can indeed write his name, Cade's ignorant followers explode, "He hath confessed - away with him! He's a villain and a traitor" (94-95), while Cade contemptuously orders, "Away with him, I say, hang him with his pen and inkhorn about his neck" (96-97). Later, Cade denounces Lord Saye's literacy on moral grounds:

Thou hast most traitorously corrupted the youth of the realm in erecting a grammar school; and, whereas our forefathers had no ... books ... thou hast caused printing to be used. ... It will be proved to thy face that thou hast men about thee that usually talk of a noun and a verb and such abominable words as no Christian ear can endure to hear. $(4.7 .27-34)^{158}$

Here, literacy is viewed as a corrupting influence, so that grammar schools and knowledge of grammar are deemed abominations and education becomes un-Christian. Thus the illiterate "mechanic" preaching of Cade misconstrues and oversimplifies the already ridiculously overstated Puritan diatribes against a supposedly evil ministry or "office of reading," one that, we have seen, one Puritan described "as evil as playing upon a stage." Indeed, Cade's clownish preaching is also consistent with Rhodes's discovery that Martin Marprelate "amalgamated" the roles of "clown and 
preacher." 159 Cade thus evokes both "Martin, the clowning preacher,"160 and the many ignorant brethren whom Puritan preachers like Younge and Baxter found sermon-proof.

Cade's stereotypical illiteracy, appearing on stage $c$. 1591-92, was also topical, recalling a recent scandalous incident that Puritan Josias Nichols called a "most grievous accident" which did "very much darken the righteousness of our cause." 161 At a time when Cartwright and eight Puritan ministers were on trial, on July 16th of 1591, two deluded Puritans, mounting a cart in Cheapside, proclaimed that they were prophets and "witnesses" with "news from Heaven" that the supposedly "gifted" William Hacket, actually merely an illiterate lunatic, was the Messiah and ruler of Europe and that the Queen had abdicated the throne. Twelve days later, Hacket's brief reign ended, as he hung from the gallows, after he had screamed shocking blasphemies and treasons to horrified onlookers. ${ }^{162}$ To the Puritans' embarrassment, the incident recalled the earlier Anabaptists' shockingly ignorant, lower-class heresy and revolt in Munster, where the zealous furrier and leather-dresser Melchior Hoffman's "wild ideas were fostered by his own lack of formal education and open contempt for learning," where his successor Jan Matthijs, "a ruthless egomaniac out of touch with reality," was to insist on the common possession of all property, and the narcissist Jan Beuckels ("John of Leyden") eventually proclaimed himself king, published a long list of sins punishable by death, and introduced polygamy to exercise his considerable lust. ${ }^{163}$

The 1591 incident - and the satirical depiction of a puritanical Cade in 2 Henry $V I$ - thus echoed the lurid propaganda Bancroft was already promoting. Seizing the opportunity to link Presbyterian Puritans to the Anabaptists, Bancroft was able to make the sensational incident "the logical climax of his literary exposure of the puritan movement" thereafter. ${ }^{164}$ Like Bancroft, after the 1591 scandal, Richard Cosin, in his Conspiracie, for pretended reformation: viz presbyteriall discipline (1592), could exploit the Hacket episode to argue that the Puritans were, like the Anabaptists, attempting to use "a hundred thousande handes for the advancement of their cause," which was to encourage "tumult and sedition." Although the "common multitude . . . did better keepe themseves out of this action than was expected," Cosin remarked, "Yet the danger thereof was [still] great." 165 Given the currency of sensational fear-mongering in orthodox propagandistic tracts and sermons, it is likely that audiences would have recalled the Hacket incident, the Anabaptists, and Puritans generally when they saw the mad, illiterate, grotesque artisan Cade zealously inciting a carnivalesque rebellion presented as "reformation." 
After all, in England, as in Switzerland, it was "the lower sort of people" who "greedily embraced the doctrines of Anabaptism," 166 and many fearfully recalled that decades earlier, in Amsterdam, Munster, and Strasbourg, Anabaptists "rose against the whole existing social order." 167 Moreover, even before the appearance of Cade, in 1589, in his An Admonition to the People of England, the propagandist Bishop Cooper put the following Cade-like question in the mouths of Presbyterian populist preachers: "[W]hy should we live in miserable slavery under those proud lords and crafty lawyers, etc," 168 while Nashe spoke contemptuously of radical mechanic preachers, some of whom even went so far as to preach that universities should be abolished and all books but the Bible burnt. ${ }^{169}$ Perhaps Cade was in reality not so ridiculously exaggerated a portrayal as he initially would seem to a modern audience.

In fact, while Jack Cade, Ralph Betts, and Tom Miller may sound very little like Puritans to a modern audience largely predisposed and conditioned to view Puritans merely as strict and learned, read in an Elizabethan context, they embody radically different anti-Puritan prejudices and stereotypes of audiences in the early 1590s. If a clown like Cade does not fit our own modern prejudices about Puritans, neither do Martin Marprelate, the clown "stricte Stupido," the "ecclesiastical cobblers" Cutbert Cliff and Humphrey Newman, the "mechanic preacher" Christopher Vittel, the illiterate madman William Hacket, or the "bellygods" Master Ful-Bellie, Zeal-of-the-Land Busy, or Plumporridge. It is inaccurate to suggest, therefore, that characterizations of the carnivalesque or of carnivalized rebellion during this period signal popular playwrights' dislike of or distancing from carnival or "the folk" generally. Rather, given the obvious religious zeal of Cade and contemporary carnivalesque clown-rebel characters, what playwrights and many conformist Protestants seem to have feared was the danger of inflammatory, populist, lower-class heresy among "the common multitude." And because carnival humor was appropriated for religious polemic, attitudes towards carnival inevitably changed. As Keith Thomas explains,

So long as the social hierarchy itself went unchallenged, the rites of inversion could be safely tolerated; their very levity reflected an underlying security: But once men had begun to question the principles of that hierarchy, then . . . the arbitrary nature [of inversion] came to seem positively dangerous.... Once the social hierarchy was challenged, the laughter of carnival and festive inversion seemed a threat rather than a support. ${ }^{170}$

More specifically, I would add, when Martin Marprelate "proclaim[ed] open war" on the Church hierarchy, employing a carnivalesque, clownish persona and "tinker's terms" — at a time when people feared popular rebellion and 
the breakdown of the social order - he prepared the way for the staging of carnivalesque, rebellious Puritan clowns in the early 1590s. Ironically, then, the evidence suggests that, as much as the Puritans' famed opposition to carnival, their lost stereotypical association with it may have contributed to a subsequent decline of carnivalesque clowning.

\section{Oglethorpe University}

\section{Notes}

1. Patrick Collinson, "Ben Jonson's Bartholomew Fair: The Theatre Constructs Puritanism," in The Theatrical City: Culture, Theatre and Politics in London, 1576-1649, ed. David L. Smith, Richard Strier, and David Bevington (Cambridge: Cambridge University Press, 1995), p. 168; Kristen Poole, "Saints Alive! Falstaff, Martin Marprelate, and the Staging of Puritanism," Shakespeare Quarterly 46 (1995): 47-75. To summarize the evidence concerning Falstaff, he constantly "resort[s] to Scriptural phraseology" and hypocritically affects the pangs "of an uneasy conscience" (J. Dover Wilson, The Fortunes of Falstaff [Cambridge and New York: Cambridge University Press, 1944], p. 16; quoted in Poole, "Saints Alive!", p. 65); cites the Bible twenty-six times in 1 Henry IV alone (Naseeb Shaheen, Biblical References in Shakespeare's History Plays [Newark: University of Deleware Press, 1989], p. 137; cited in Poole, "Saints Alive!", p. 65); and uses Puritan cant (e.g., he refers to himself as a "saint" corrupted by "the wicked" [1H4, 1.2.88-93] and speaks of his "vocation" [101-2] and, repeatedly, of "the spirit" [e.g., 2H4, 3.2.253-55]; as cited in Poole, "Saints Alive!", p. 66). In 2 Henry IV, Hal insistently mocks Falstaff's Puritan cant, false piety, and occasional affected puritanical zeal (2.4.324-27; as cited in Poole, "Saints Alive!", pp. 66-67). Above all, Falstaff shares with stereotypical Puritans a "levelling tendency" that "explodes sanctioned hierarchies," since his insults to Hal "are just as dismissive of hierarchy as are those of Martin [Marprelate] to the bishops" (Poole, "Saints Alive!", p. 70). In addition, Shakespeare's "Falstaff" initially appeared with the name of the Lollard "Oldcastle," presented as an heroic proto-Puritan martyr in Foxe's Acts and Monuments.

2. My use of the term "Puritan" throughout echoes that of historian Peter Lake, Anglicans and Puritans?: Presbyterianism and English Conformist Thought from Whitgift to Hooker (London: Unwin Hyman, 1988), p. 7:

The term "puritan" is used to refer to a broader span of opinion [than the presbyterian platform alone], encompassing those advanced protestants who regarded themselves as "the godly.". . . It is therefore used as a term of degree, or relative religious zeal rather than as a clear-cut party label. Thus, while all presbyterians were puritans, not all puritans were presbyterians. ...

For further discussion of such issues, see Patrick Collinson, "Concerning the Name Puritan, a Comment," Journal of Ecclesiastical History 31 (1980): 463-88, and Peter Lake, "Defining Puritanism - Again?," in Puritanism, ed. F. Bremer (Boston: Massachusetts Historical Society, 1993), pp. 3-29.

3. Keith Thomas, "The Place of Laughter in Tudor and Stuart England," Times Literary Supplement 21 January 1977: 79.

4. Keith Wrightson, "Order," in English Society, 1580-1680 (New Brunswick, NJ: Rutgers University Press, 1982), p. 149; David Underdown, "The Taming of the Scold," in Order and Disorder in Early Modern England, ed. Anthony Fletcher and John Stevenson (Cambridge 
60 / Renaissance and Reformation / Renaissance et Réforme

University Press, 1985), p. 116. See also David Underdown, Revel, Riot, and Rebellion: Popular Politics and Culture in England, 1603-1660 (Oxford: Clarendon Press, 1985).

5. Records of the Churches of Christ, Gathered at Fenstanton, Warboys, and Hexham, 1640-1720, ed. E. B. Underhill (London: Hanserd Knollys Society, 1854), p. 422.

6. See Peter Burke, "The World Upside Down," in Popular Culture in Early Modern Europe (New York: Harper and Row, 1978), pp. 185-99.

7. Gerrard Winstanley, A Watch-Word to the City of London (1649), in The Works of Gerrard Winstanley, ed. G. H. Sabine (Ithaca, NY: Cornell University Press, 1941), pp. 316-17.

8. Richard Hooker, Of the Laws of Ecclesiastical Polity, 3 vols., Everyman's Library (London: Dent; New York: Dutton, 1907), 1: 132; quoted in Christopher Hill, The World Upside Down: Radical Ideas During the English Revolution (London: Penguin, 1972), p. 32.

9. A Suplication of the Family of Loue (said to be presented in the Kings royall hands, knowen to be dispersed among his loyall Subiectes) for grace and favour. Examined, and found to be derogatorie in an hie degree, unto the glorie of God, the honour of our King, and the Religion in this Realme both soundly professed \& firmly established (Cambridge, 1606), p. 19. On Familism generally, see C. Marsh, The Family of Love in English Society, 1550-1630 (Cambridge: Cambridge University Press, 1994); Janet E. Haley, "Heresy, Orthodoxy, and the Politics of Religious Discourse: The Case of the English Family of Love," in Representing the English Renaissance, ed. Stephen Greenblatt (Berkeley: University of California Press, 1988), pp. 303-25; Alistair Hamilton, The Family of Love (Cambridge: Cambridge University Press, 1981); and the bibliography provided by Joan Dietz Moss, "Variations on a Theme: The Family of Love in Renaissance England," Renaissance Quarterly 31 (1978): 186-87n.

10. Robert Crowley, An Informacion and Petition agaynst the oppressours of the pore Commons of this Realme (1548 or 1549), in Select Works, ed. J. M. Cowper, Early English Text Society (1872); quoted in Christopher Hill, The English Bible and the Seventeenth-Century Revolution (London: Penguin, 1993), p. 201.

11. James Pilkington, "Exposition upon the Prophet Aggeus," in The Workes of James Pilkington (Cambridge: Cambridge University Press for the Parker Society, 1842), p. 125.

12. On Bancroft, see Annabel Patterson, Shakespeare and the Popular Voice (Oxford: Blackwell, 1989), pp. 39, 46. The Life and Death of Jack Straw, to be discussed below, actually depicts the incitements of the historical Parson John Ball, who provoked the riots by his sermons and by speaking the notorious verse. See R. B. Dobson, ed., The Peasants' Revolt of 1381 (London: Macmillan, 1970), pp. 390-91.

13. Joseph Black, "The Rhetoric of Reaction: The Martin Marprelate Tracts (1588-89), Anti-Martinism and the Uses of Print in Early Modern England," The Sixteenth Century Journal 28 (1997): 719.

14. James I, The True Law of Free Monarchies and Basilikon Doron, ed. Daniel Fischlin and Mark Fortier (Toronto: Centre for Reformation and Renaissance Studies, 1996), p. 94.

15. Correspondence of Matthew Parker, D. D., Archbishop of Canterbury: Comprising Letters Written by and to Him, from A.D. 1535 to His Death, A.D. 1575, ed. John Bruce and Thomas Thomason Perowne, Parker Society Publications 33 (Cambridge: Cambridge University Press for the Parker Society, 1853), p. 437.

16. Whitgift is quoted in Patrick Collinson, The Elizabethan Puritan Movement (1967; rpt. Oxford: Clarendon Press, 1990), p. 137. All subsequent citations of Collinson refer to this work. 
17. Matthew Sutcliffe, An Answere to a certaine libel supplicatorie (London, 1592), p. 72. On Anabaptist rebellion on the Continent, see Bernard M. G. Reardon, Religious Thought in the Reformation, 2nd ed. (London: Longman, 1995), pp. 196-207.

18. John Whitgift, The Works of John Whitgift, ed. John Ayre, 3 vols., Parker Society Publications 46 (Cambridge: Cambridge University Press for the Parker Society, 1851), 1: 466.

19. Richard Bancroft, Tracts Ascribed to Richard Bancroft: Edited from a Manuscript in the Library of St. John's College, Cambridge, ed. Albert Peel (Cambridge: Cambridge University Press, 1953), p. 83.

20. Burghley is quoted in Christopher Hill, Change and Continuity in Seventeenth-Century England, rev. ed. (New Haven, CT: Yale University Press, 1991), p. 192.

21. Richard Bancroft, A Sermon preached at Paules Crosse the 9. of Februarie . . 1588 (London, 1589), pp. 86-87.

22. Hill, World Upside Down, p. 77.

23. Hill, English Bible, pp. 56-57.

24. Cited by Hill, English Bible, p. 59.

25. Martin Marprelate [pseud.], The Epistle (1588), in The Marprelate Tracts (1588-1589) (facsimile reprint; Leeds: The Scolar Press, 1967), p. 7. All subsequent citations from Marprelate refer to this edition.

26. William Barlow, The Summe and the Substance of the Conference, which, it Pleased his Excellent Majestie to Have ... at Hampton Court (London, 1604), pp. 36, 82.

27. William Tyndale, Doctrinal Treatises, and Introductions to Different Portions of the Holy Scriptures, ed. Henry Walter (Cambridge: Cambridge University Press for the Parker Society, 1848), p. 247.

28. Hill, World Upside Down, pp. 31-32.

29. Thomas Cooper, An Admonition to the People of England: wherein are answered, not onely the slanderous untruethes, uttered by Martin, but also other crimes (1589), ed. E. Arber (London: Constable, 1895), p. 118.

30. Richard Sibbes, A Heavenly Conference between Christ and Mary (1654), in The Collected Works of Richard Sibbes, ed. Alexander B. Grosart, 6 vols. (Edinburgh: Banner of Truth Trust, 1862-64), 6: 458.

31. Cited in Hill, Change and Continuity, p. 189; emphasis added.

32. Certain Sermons, etc. (1560), sigs. Riiii ${ }^{\mathrm{r}-\mathrm{v}}$; cited in Hill, Change and Continuity, p. 189.

33. Collinson, p. 391.

34. Christopher Hill, Writing and Revolution in 17th-Century England, vol. 1 of The Collected Essays of Christopher Hill (Amherst: University of Massachusetts Press, 1985), p. 75.

35. Hay any worke for Cooper? (1589), in The Marprelate Tracts (1588-1589), p. 14.

36. Ibid.

37. The Epistle, p. 43.

38. Anne Lake Prescott, Imagining Rabelais in Renaissance England (New Haven, CT: Yale University Press, 1998), p. 38

39. The Epistle, p. 39; the slashes appear in the original text, often instead of commas.

40. Ibid., p. 33. 
62 / Renaissance and Reformation / Renaissance et Réforme

41. See Roger Lockyer, Tudor and Stuart Britain, 1471-1714 (New York: St. Martin's Press, 1993), p. 164.

42. Black, p. 713. Black also quotes Whitgift giving credit to Bancroft: "By his advice, that Course was taken, which did principally stop Martin and his Fellows' mouths viz: to have answered after their own vein in writings" (Black, p. 712).

43. Josias Nichols, The plea of the innocent (1602), pp. 32-33; quoted in Collinson, p. 393.

44. Collinson, p. 393.

45. Ibid., pp. 137, 400.

46. Thomas Digges, Humble motives for association to maintaine religion established (1601), pp. 24-25; quoted in Collinson, p. 388.

47. From Autobiography (1615-1633), cited in Lionel Arthur Grovett, The King's Book of Sports: A History of the Declarations of King James I and King Charles I as to the Use of Lawful Sports on Sundays, etc. (London: Eliott Stock, 1890), p. 6; emphasis added.

48. Hill, Writing and Revolution, p. 77.

49. Tudor Royal Proclamations, ed. Paul L. Hughes and James F. Larkin, vol. 3 (The Later Tudors, 1588-1603) (New Haven, CT: Yale University Press, 1969), p. 34.

50. Cooper, p. 36.

51. John Lyly, Mar-Martine (1589), in The Complete Works of John Lyly: Now for the First Time Collected and Edited from the Earliest Quartos with Life, Bibliography, Essays, Notes, and Index, ed. R. Warwick Bond, 3 vols. (Oxford: Clarendon Press, 1902), 3: 423, 11. 5-6.

52. Lyly, A Whip for an Ape (1589), in Bond, ed., Works, 3: 418, 1. 14.

53. Ibid., 3: 421, 1. 84.

54. Ibid ., 3: 420, 11.124-26.

55. Lyly, Mar-Martine, 3: 423, 1. 16.

56. Quoted in Black, pp. 721-22.

57. Thomas Nashe, The Returne of the Renowned Cavaliero Pasquill of England (1589), in Works: Edited from the Original Texts, ed. R. B. McKerrow, 5 vols. (London: A. H. Bullen, 1904-11), 1: 83.

58. Nashe, An Almond for a Parrat (1590), in McKerrow, ed., Works, 3: 341.

59. Ibid., 3: 374 .

60. Nashe, The Returne of the Renowned Cavaliero Pasquill, 1: 92.

61. Nashe, A Countercuffe giuen to Martin Iunior (1589), in McKerrow, ed., Works, 1: 59.

62. Poole, “Saints Alive!”, p. 59.

63. See E. K. Chambers, "Documents of Criticism," in The Elizabethan Stage, 4 vols. (Oxford: Clarendon Press, 1923), 4: 229-33.

64. Nashe, A Countercuffe, 1: 59.

65. Lyly, Pappe with an hatchet (1589), in Bond, ed., Works, 3: 408.

66. Quoted in Chambers, 4: 233.

67. Ibid., 4: 230. 
68. Charles Nicholl, A Cup of News: The Life of Thomas Nashe (London: Routledge and Kegan Paul, 1984), pp. 68, 288-89n27.

69. Lyly, Pappe with an hatchet, 3: 408.

70. Quoted in Chambers, 4: 306.

71. Ibid., 1: 295.

72. Martin Iuniors Epilogve (1589), in The Marprelate Tracts (1588-1589), sig. D3v .

73. The Epistle, p. 81.

74. The Protestacyon (1589), in The Marprelate Tracts (1588-1589), p. 4.

75. Richard Helgerson, Forms of Nationhood: The Elizabethan Writing of England (Chicago: University of Chicago Press, 1992), p. 220.

76. Ibid., p. 221.

77. Ibid., p. 245. On this element in The Play of Sir Thomas More, see also Simon Hunt, “Leaving Out the Insurrection': Carnival Rebellion, English History Plays, and a Hermeneutics of Advocacy," in Renaissance Culture and the Everyday, ed. Patricia Fumerton and Simon Hunt (Philadelphia: University of Pennsylvania Press, 1999), pp. 299-314.

78. Helgerson, p. 245.

79. Ibid., p. 222. Helgerson goes so far as to claim that "popular, marginal, subversive, and folk ... were the very labels ... from which [would-be elites in the theater, particularly many authors] were striving to free themselves" (p. 245).

80. David Wiles, Shakespeare's Clown: Actor and Text in the Elizabethan Playhouse (Cambridge: Cambridge University Press, 1987), p. 20.

81. Meredith Anne Skura, Shakespeare the Actor and the Purpose of Playing (Chicago: University of Chicago Press, 1993), pp. 57-58, here quoting Wilhelm Creizenach, The English Drama in the Age of Shakespeare, trans. from Geschichte des neueren Dramas (1916; rpt. New York: Haskell House, 1964), p. 184. For further information on Tarlton, see also Edwin Nungezer, A Dictionary of Actors and of Other Persons Associated with the Public Representation of Plays in England before 1642 (New York: Greenwood, 1968), pp. 347-65.

82. Skura, p. 58.

83. Ibid., p. 59.

84. Ibid., p. 54.

85. Curiously, Helgerson seems to be aware that mocking low-class clowns was not actually novel in Shakespeare's work, as he concedes that Tarlton's clowns were "the fall guy, the ignorant victim" and that audiences "laugh[ed] at the oafish countryman" (p. 216; emphasis added).

86. Lyly, Whip for an Ape, 3: 319, 11. 53-54.

87. Ibid., 3: 416, 11. 106-7.

88. Donna B. Hamilton, Shakespeare and the Politics of Protestant England (Lexington: University of Kentucky Press, 1992), p. 76.

89. Lyly, Pappe with an hatchet, 3: 408.

90. Nashe, An Almond for a Parrat, 3: 344.

91. Black, p. 719. The term "mechanic preachers" refers here to a type, not to a direct anti-Martinist statement, although Nashe frequently alluded to this type. See, for instance, 
64 / Renaissance and Reformation / Renaissance et Réforme

the "base mechanicall fellow ... sprung out of the mudde ... who for foure yeeres together . . . went crying vp and downe, Woe to Ierusalem . . . , woe to euery liuing thing that breatheth therin" (Nashe, Christs Teares Over Iervsalem [1593], in McKerrow, ed., Works, 2: 62). For a discussion of an actual "mechanic preacher," see J. W. Martin, "Christopher Vitel: An Elizabethan Mechanic Preacher," The Sixteenth Century Journal 10 (1979): $15-22$.

92. Nicholl, p. 65.

93. Lyly, Mar-Martin, 3: 426, 11. 97 and 98.

94. Nashe, Pierce Penilesse (1592), in McKerrow, ed., Works, 1: 192.

95. Nashe, An Almond for a Parrat, 3: 351.

96. Nicholl, p. 77.

97. Martin, pp. 15-22.

98. The Epistle, p. 60.

99. Robert Wilson, The Cobbler's Prophecy (1594), ed. A. C. Wood (Oxford: Oxford University Press for the Malone Society, 1914), sig. B4v , 11. 332-35.

100. Quoted in William C. Carroll, Fat King, Lean Beggar: Representations of Poverty in the Age of Shakespeare (Ithaca, NY: Cornell University Press, 1996), p. 142.

101. William B. Long, "The Occasion of The Book of Sir Thomas More," in Shakespeare and Sir Thomas More : Essays on the Play and its Shakespearian Interest, ed. T. H. Howard-Hill (Cambridge: Cambridge University Press, 1989), p. 50. Surprisingly, despite making the connection to an anti-Martinist here, Long does not go on to argue that the revision is linked to anti-Puritanism.

102. Ibid., p. 45.

103. Vittorio Gabrieli and Giorgio Melchiori, eds., Sir Thomas More: A Play by Anthony Munday and Others, Revels Plays (Manchester: Manchester University Press, 1990), p. 27. Subsequent citations from the play are taken from this edition and will be documented parenthetically.

104. Collinson, p. 428.

105. Donna B. Hamilton, p. 8.

106. Collinson, p. 431.

107. Donna B. Hamilton, p. 8.

108. Collinson, p. 428.

109. Donna B. Hamilton, p. 8.

110. Ibid.

111. Richard Bancroft, Dangerous positions and proceedings published and practised within this island of Britayne (London, 1593), sig. Aa3 ${ }^{\mathrm{v}}$.

112. Ibid., sig. Q4v

113. The Pilgrimage to Parnassus with the Two Parts of the Return from Parnassus: Three Comedies performed in St. John's College (1597-1601), ed. W. D. Macray (London: Clarendon Press, 1886). All subsequent citations of the play refer to this edition and will be documented parenthetically. 
114. Ben Jonson, Bartholomew Fair, ed. G. R. Hibbard, The New Mermaids (1977; rpt: London: Black, 1994), 2.1.90, 4.6.99, 5.2.55, 5.2.66, 5.5.8, 5.5.11. All subsequent citations of the play refer to this edition and will be documented parenthetically.

115. Jonathan V. Crewe, "The Theater of Idols: Theatrical and Anti-theatrical Discourse," in Staging the Renaissance: Reinterpretations of Elizabethan and Jacobean Drama, ed. David Scott Kastan and Peter Stallybrass (New York: Routledge, 1991), p. 55. Crewe does not discuss Sir Thomas More but rather Puritan discourse generally.

116. Long, pp. 50-51.

117. Nicholl, p. 76. Nicholl does not refer to Sir Thomas More.

118. Long, pp. 50-51.

119. See Dobson, pp. 390-91.

120. Lyly, Whip for an Ape , 3: 420, 11. 89-90; Rimes against Marprelate is quoted in Helgerson, p. 250, though he does not take up the connection between rebellion and Puritanism.

121. The Life and Death of Jack Straw (pub.1593), ed. Kenneth Muir and F. P. Wilson (Oxford: Oxford University Press for The Malone Society, 1957), 11. 47-48. All subsequent citations refer to this edition and will be documented parenthetically.

122. Geoffrey Chaucer, "General Prologue" (1. 478) and "Epilogue" to "The Man of Law's Tale" (11. 1173, 1177), The Canterbury Tales, in The Riverside Chaucer, gen. ed. Larry D. Benson, 3rd ed. (Boston: Houghton Mifflin, 1987).

123. Burke, pp. 53, 175.

124. Thomas Hooker, The Soules Preparation for Christ (1632), p. 70.

125. Richard Younge, A Hopefull Way to Cure that Horrid Sinne of Swearing (London, 1645), p. 412.

126. Richard Baxter, The Reformed Pastor (London, 1656), p. 357.

127. Ibid., pp. 431-32.

128. Donna B. Hamilton, p. 76.

129. All citations from 2 Henry VI refer to The Norton Shakespeare Based on the Oxford Edition, gen. ed. Stephen Greenblatt (New York: Norton, 1997), and will be documented parenthetically. There is no agreement as to the date of composition of 2 Henry VI. Whereas the Norton Shakespeare editors argue that the date of the play is "probably" 1591 (p. 203), Hanspeter Born argues for a date "between March and August 1592" in "The Date of 2, 3 Henry VI," Shakespeare Quarterly 25 (1974): 334. Similarly, New Cambridge editor Michael Hattaway presents a case that "the whole sequence [parts 1, 2, and 3] was written some time before March 1592" (William Shakespeare, The Second Part of King Henry VI, ed. Michael Hattaway, The New Cambridge Shakespeare [Cambridge: Cambridge University Press, 1991], p. 68).

130. Ronald Knowles, ed., King Henry VI Part 2, The Arden Shakespeare (Walton-on-Thames, Surrey: Thomas Nelson, 1999), p. 299. Likewise, when Cade praises the Butcher, saying, "They fell before thee like sheep and oxen" (4.3.3), Knowles notes: "There is possibly an illusion here to the Israelites fighting the Philistines: see 1 Samuel, 14.32” (p. 311).

131. See Knowles, ed., King Henry VI Part 2, p. 300, n. to 11. 31-32: "Cf. Leviticus, 26.8, `and your enemies shall fall before you upon the sword'... . Texts like Ezekiel, 21.26, 'Remove the diadem, and take off the crown ... exalt him that is low, and abase him that is high', and Luke, 1.52, 'He hath put down the mighty from their seats, and exalted them of low degree,' provided a revolutionary agenda for the Anabaptist leaders, as in Thomas 
66 / Renaissance and Reformation / Renaissance et Réforme

Muntzer's `Special Exposure of False Faith' (1524).” Knowles, however, does not argue that Cade and his followers are Puritan.

132. Lyly, Pappe with an hatchet, 3: 409.

133. Nashe, The Unfortunate Traveller, or, The Life of Jacke Wilton (1594), in McKerrow, ed., Works, 2: 232.

134. Ibid., 2: 233.

135. Ibid., 2: 241.

136. Hunt, p. 304.

137. Nashe, Pierce Penilesse, 1: 172.

138. Michael D. Bristol, Carnival and Theater: Plebeian Culture and the Structure of Authority in Renaissance England (New York: Methuen, 1985), p. 77.

139. John Taylor, All the Workes of Iohn Taylor "The Water Poet" Collected Into One Volume (1630; facsimile reprint; London: The Scolar Press, 1973), p. 118.

140. Nashe, An Almond for a Parrat, 3: 374.

141. Taylor, p. 119. Note the parallel between "the disordered businesse is so ordered" and Cade's anarchic claim: "then are we in order when we are most out of order" (4.2.172-73).

142. Christopher Hill, Society and Puritanism in Pre-Revolutionary England (New York: St. Martin's, 1997), p. 13. For a full discussion of the type of the hypocritical Puritan glutton or "bellygod," see especially Kristen Poole, "Eating Disorder: Feasting, Fasting, and the Puritan Bellygod at Bartholomew Fair," in Radical Religion from Shakespeare to Milton: Figures of Nonconformity in Early Modern England (Cambridge: Cambridge University Press, 2000), pp. 45-73. Neither Hill nor Poole deals with Cade.

143. Poole, Radical Religion, p. 60.

144. Neil Rhodes, Elizabethan Grotesque (London: Routledge and Kegan Paul, 1980), p. 158. Rhodes speaks here of an innovation evident in the Marprelate and anti-Martinist tracts in his discussion of the development of satirical prose journalism in the 1590s, but his findings are related to the parallel development of the stage clown at this time.

145. Note that these lines appear in the 1594 Quarto, not in the 1623 Folio text. As the Textual Note in The Norton Shakespeare records, "[t]hese additions, lines 116-31 and 134-36 of 4.7, report the burning of London Bridge, the rape of the Sergeant's wife by one of Cade's men, and Cade's own boast that he will lead his men in sexual assaults upon the women of the city" (p. 211). The effect, I would suggest, is to develop Cade's Puritan character by way of the stereotype of loutish Anabaptist revolutionaries so prevalent in the early 1590s. That the Quarto lines are "additions" resulting from memorial reconstruction, rather than being Shakespearean in origin and subsequently cut in the later Folio text, is far from certain. See Steven Urkowitz, "If I Mistake in These Foundations Which I Build Upon': Peter Alexander's Textual Analysis of Henry VI Parts 2 and 3," ELR 18 (1988): 230-56.

146. Here again, the latter quote appears only in the 1594 Quarto.

147. Donna B. Hamilton, p. 77.

148. Ibid.

149. Ibid.

150. Ibid.

151. Ibid., p. 78 . 
152. Knowles, ed., p. 324, n. 79; emphasis added.

153. Nicholl, p. 87. Nashe, according to Nicholl, was certainly writing plays at this time, since Robert Greene lists him along with Marlowe and Peele "as one of those `fellow Schollers about this Cittie' that 'spend their wits in making Plaies"' (quoted in Nicholl, p. 86). Likewise, during a season when the theaters were closed, Nashe wrote bitterly of the "harvest [he] expected by writing for the stage" (quoted in Nicholl, p. 236).

154. Nashe, Unfortunate Traveller, p. 209.

155. Sutcliffe, sig. A2 ${ }^{\mathrm{v}}$.

156. Hay any worke for Cooper?, prefatory epistle, sig. $3^{\mathrm{v}}$.

157. Quoted in Religion and Society in Early Modern England, a Sourcebook, ed. David Cressy and Lori Anne Ferrell (London: Routledge, 1996), p. 84; emphasis added.

158. Compare Cade's zealous diatribe here with a Puritan attack on university education as imitated by Nashe:

Sir Peter nor Sir Paul were neuer Archbishoppes of Canterbury. . . . They were Fisher-men. . . They were none of these .. . Graduates, nor Doctors, therefore why should we tie our Ministrie to the prophane studies of the Vniversitie? What is Logicke but . . . a world of bibble babble. Neede we anie of your Greeke, Latine, Hebreue, or anie such gibberige, when wee haue the word of God in English? Go to, go to, you are a great company of vaine men, that stand vpon your degrees and tongues with tittle tattle, I cannot tell what, when . . . the Apostles knew neare a Letter of the booke. (An Almond for a Parrat, 3: 350)

159. Rhodes, p. 115. Rhodes's argument here about "satirical [prose] journalism" (p. 158) and its use of the grotesque in the 1590s ultimately informs his reading of the development of the stage clown in terms of the influence of Marprelate and Nashe. See especially his discussion in Chapter 6, "Shakespearean Grotesque: the Falstaff Plays" (pp. 89-130). Rhodes does not, however, address a religious context for the grotesque or for his analysis of Martin.

160. Ibid., p. 4.

161. Josias Nichols, The plea of the innocent (1602), pp. 32-33; quoted in Collinson, p. 393.

162. Collinson, p. 424.

163. Reardon, pp. 203-4.

164. Collinson, p. 424.

165. Quoted in Carroll, p. 142.

166. Hill, World Upside Down, pp. 35, 161.

167. Collinson, p. 424.

168. Cooper, p. 118. By comparison, in 2 Henry VI, one of Cade's followers cries, "The first thing we do let's kill all the lawyers" (4.2.68).

169. Hill, English Bible, p. 199.

170. Thomas, pp. 79,81 . 